\title{
Cultural Effects of Economic Activity Minangkabau Society
}

\author{
Eliza $^{1}$, Danarti hariani $^{2}$, D.Pratama ${ }^{3}$ \\ Sekolah Tinggi Perpajakan, Indonesia ${ }^{1}$ \\ Universitas Mohammad Husni Thamrin, Indonesia ${ }^{2}$ \\ Universitas Indraprasta PGRI, Indonesia ${ }^{3}$ \\ \{elizanayla@gmail.com $\left.{ }^{1}, \underline{\text { danarti@thamrin.ac.id }}{ }^{2}\right\}$
}

\begin{abstract}
The Republic of Indonesia is a country with many islands, each of which has different cultural and social characteristics. The social and cultural characteristics of each island contribute with various colors in the life of the unitary state of the Republic of Indonesia. One of these contributions can be seen from the economic aspect. Economics and culture are believed to have closely related relationships. This paper tries to see the relation between local culture and the economic activities of the community, with the object of research on the Minang tribe in West Sumatra.
\end{abstract}

Keywords: Cultural Values, Models Of Economic Activities, Minangkabau People

\section{Introduction}

There have been several studies that discuss the link between culture and economic activity. One of the results of the study that illustrates the cultural impact on the economy is the research conducted by Ferdinal Asmin on Chavobhasi's article which ensures that economic development cannot be separated from culture. Therefore cultural destruction's values is a form of terrorism against the economic development of a nation [1]. While FuJiang Sun discusses how the relationship between cultural values to the economy and politics. That the cultural values formed by a society will influence the economic and political activities they carry out [2].

This paper discusses how culture and tradition play a role in determining economic activities to fulfill their life needs. Focusing on the culture and traditions of the Minangkabau tribe. We easily find that most of the traders are from the Minangkabau tribe. The choice of entrepreneurship or trading as an economic activity for the Minangkabau tribe also applies to those who migrate out of their hometowns. They formed a Gebu Minang Community Economic Institution or Lembaga Ekonomi Umat (LEU). Gebu Minang, who at its inception was just a fundraising movement to build infrastructure in the Halaman village, has now become a community economic empowerment movement. One program is to build shops or outlets under the name of Gebu Minang Mart. The aim is to accommodate and facilitate the very thick spirit of the Minangkabau people. 
This paper tries to answer why in general many Minang people choose to become entrepreneurs or trade than become employees? Is there a connection between Minangkabau culture and traditions for their choice of entrepreneurship?

\section{Method}

This paper is made using descriptive research methods. By looking at the phenomena that is in the activities of the Minangkabau tribal economic activities, both those that are happening now and in the past. Based on several research results that have been made before as a foundation with a different perspective of discussion and equipped with supporting data. So that, in the end, got a conclusion.

Data collection was carried out with literature studies and direct interviews with several merchant communities from the Minangkabau. Interviews with traders are limited to the Jakarta area markets, with consideration because Jakarta is their main destination for migrants. Market samples are taken randomly for several markets in Jakarta.

\section{Results and discussion}

The Minangkabau culture and traditions that are very popular and which have become the hallmark of the Minangkabau are migrating and trading. In general, the Minangkabau tribe migrated out of their hometowns with the aim of improving their economy, increasing their welfare. According to Kato, even though the Minangkabau ethnic groups left their hometown does not mean they forget their homeland, because in general, they will later return to their homeland [3].

Economic activities that are generally carried out by Minangkabau people are entrepreneurship, self-employment or trading. This choice is taken because the spirit of trade or entrepreneurship is already very thick in Minangkabau culture. They are familiar and have an ability that has indeed been hereditarily preserved in the Minangkabau community. In addition to trading, not a few Minangkabau people who have cooking skills open Padang food stalls. Minangkabau culture and traditions contribute to their choice of economic activity. Most of them tend to work as traders or entrepreneurship compared to being an employee. This applies not only to those who are in their hometowns but also those who overseas also choose the profession as traders or entrepreneurs. So almost in every market, we can easily find traders from the Minangkabau people.

\subsection{Culture in society}

Society is a collection of several humans in an area where they interact with each other to fulfill their needs. Because human beings are social beings who cannot live alone. From this society, the values of a society that will develop into culture will be born. The culture of the people in certain regions will be different from the culture of the people in other regions. Because each community group has a different aspect of value. And culture is also influenced by language, geographical conditions, and trust.

Culture is something that is hereditary, passed down from the previous generation to the next generation and usually will continue to be preserved as a guide in behaving in social life. 


\subsection{Minangkabau Culture and Traditions}

Merantau or migrate from the hometown to other place or region and trade are two Minangkabau tribal traditions that are already very popular. Two characters of the Minang culture are very thick, as a characteristic that distinguishes the Minangkabau culture from other cultures. Even if the tradition of migrating is also true in other regions, only the Minangkabau people migrate. relatively more and they are the ones who popularized the term migrate, to the term migrate attached to the identity of a person who is Minang. Generally, they migrate by armed with the spirit of entrepreneurship that is high, entrepreneurship which is mostly done for example trading or opening a Padang restaurant business. We can easily find Padang restaurants in every region in Indonesia,

The migratory tradition for the Minangkabau people was originally only for boys, while the Minang women were in charge of managing the inheritance [3]. Men wander to seek fortune in other areas. Although the Minang people went to wander, his love for the area of origin would bring him back home. They still think of the camp yard because usually, they will return to their homeland. Going for the Minang people is not just a tradition that does not produce benefits, not just leaving the village. Every migrant has a goal to be better in terms of economics in the field of education. In Minangkabaudikenal culture, the apostate raso jo pareso (taste and check) is one form of self-introspection. A person from the Minangkabau youth will be embarrassed if he continues to stay at home and rely on his parents to fulfill his life needs [3]. Merantau also arouses a sense of love for the hometown. Monitoring can bring together people closer together.

Minangkabau boys when they enter primary school usually begin to be separated to not sleep in one house with their parents. In general, they sleep with fellow peers in Surau. From this moment they began to get an understanding of the lives of migrants.

Damsar and Indriyani. According to them the socialization of migrants has occurred when a child is around seven years old. At that age a person is encouraged not to sleep at home, directed to sleep in jest. They were told they were prepared to face the outside world and were given an overview of the rantau by their seniors who had migrated or migrants who were returning home [4].

Trading is an economic behavior that is very typical of the Minangkabau tribe. Good for those who are in the yard and for those who migrate. Customs and traditions of the Minangkabau tribe based on the philosophy of Islam, make the work of trading or entrepreneurship seen as an imperative or something that is bound to self-identity, becomes a pride. Based on the results of direct interviews with several traders (originating from Minangkabau) in the market in the region Jakarta, such as the Tanah Abang, Jatinegara, and Pasar Senen markets. What reasons caused them to choose to trade or entrepreneurship, opened food-eating stalls, most of them answered because it had become a tradition passed down from the previous generation. Besides that there are also those who answer because trading is a job that follows the Sunnah of Prophet Muhammad SAW. As we know that the majority of the Minangkabau tribe are Muslim. This is reinforced by the philosophy of Minangkabau culture that is very thick with the teachings of Islam. In fact, some government regulations in West Sumatra are based on Islamic religious law [5]. As the traditional attire of 
the Minangkabau tribe, called baju kurung, is a cultural image based on the principles of Islamic Shari'a, the nature of clothing is not just fashion but has more meaning than that, which closes the genitals and is not strict. work, due to the limitations of the level of education they take makes trading the career choice that is most suitable for them.

Although not all Minangkabau people are mainly engaged in trading or entrepreneurship, in numbers the number of those who are self-employed or self-employed is still greater than those who are employees. Based on data from the Central Sumatra Provincial Statistics Agency, the choice of the main job for those who enter the age of the workforce is still more on the choice of entrepreneurship, either by working alone or assisted by several subordinates. As can be seen in the table below

Table 1. Comparison of Work between Employees and Entrepreneurs (Source: Central Statistics Board)

\begin{tabular}{|c|c|c|c|c|c|c|c|c|c|c|c|}
\hline No. & JOB STATUS & 2006 & 2007 & 2008 & 2009 & 2010 & 2011 & 2012 & 2013 & 2014 & 2015 \\
\hline \multirow[t]{5}{*}{1} & ENTERPRENEURSHIP & 895.556 & 914.904 & 936.807 & 956.121 & 936.807 & 931.002 & 908.587 & 936.213 & 1.003 .245 & 927.262 \\
\hline & a. self-employee & 481.847 & 456.993 & 434.206 & 455.905 & 434.206 & 456.634 & 452.260 & 475.441 & 524.627 & 464.552 \\
\hline & b. to be helped by temporary workers & 362.768 & 401.636 & 414.894 & 425.744 & 414.894 & 360.860 & 356.261 & 364.674 & 383.158 & 382.435 \\
\hline & c. to be helped by permanent workers & 50.941 & 56.275 & 87.707 & 74.472 & 87.707 & 113.508 & 100.066 & 96.098 & 95.460 & 80.275 \\
\hline & & & & & & & & & & & \\
\hline \multirow[t]{5}{*}{2} & Occupation: & 623.324 & 640.329 & 759.406 & 696.120 & 759.406 & 810.342 & 872.158 & 834.994 & 894.952 & 957.370 \\
\hline & a. employee & 442.791 & 469.196 & 537.176 & 434.517 & 537.176 & 592.186 & 644.387 & 636.261 & 678.407 & 697.136 \\
\hline & b. freelancer in agriculture & 94.912 & 104.204 & 125.424 & 156.288 & 125.424 & 118.204 & 120.133 & 111.210 & 112.832 & 125.231 \\
\hline & c. freelancer in non agriculture & 85.621 & 66.929 & 96.806 & 105.315 & 96.806 & 99.952 & 107.638 & 87.523 & 103.713 & 135.003 \\
\hline & & & & & & & & & & & \\
\hline
\end{tabular}

Primajati formulates several characters that are inherent in the entrepreneurial spirit of Minangkabau people, among others, as follows [6];

1. Strong self-confidence, feels honored to be an entrepreneur and not being an employee

2. Hard worker; because he is fully responsible for his business, to continue to survive and advance, this is different from the character of an employee

3. Careful calculations / economical,

4. Independence; since childhood, the Minangkabau tribe has accustomed their children not to depend on parents,

5. Contributions to the family,

6. Consistent,

7. Dare to take risks.

Trading is the main job as a characteristic of the Minangkabau tribe. In Minangkabau custom, there are two basic principles in economic behavior, namely balance, and justice. Balanced is interpreted as a simple life, not excessive, economical and not wasteful. Steer clear of the extravagance known in Minang's proverb: Wakto ado jan is eaten newly. (meaning that when it is not eaten it has just been eaten) the meaning contained in the custom philosophy is; When young and strong work as hard as you can and collect as much wealth as possible while at old age enjoy what you get when you are young. While justice is meant to be mutual tolerance among others and mutual respect. Differences in ability do not become a reason that someone can oppress or exploit others [4].

Merantau makes their kinship closer. So this makes it easier for them to coöperate with each other in economic activities on the principle of balance and justice. One manifestation of 
this condition is the Movement to collect donations of one thousand Rupiahs per month from overseas Minangkabau people. The funds collected are used for the construction of infrastructure in their hometown. It is known as Gebu Minang

Gebu Minang, which at its inception was a movement to collect donations of one thousand Rupiahs/month from all Minangkabau people who were built to build facilities and infrastructure in their hometown, has now turned into the Society of Economic Institutions, with one of its programs being to build shops called Gebu Minang Mart. Gebu Minang Mart as a form of independence and a reflection of the spirit of Minangkabau tribe entrepreneurs

\section{Conclusion}

Values contain in culture and Minangkabau tribal traditions offer guidance on how they behave in economic activities. The guidance is also an identity of a Minangkabau person. And this is passed down from the previous generation to the next generation. Economic activities to fulfill living needs and improve welfare are carried out by means of trading or entrepreneurship. Because trading or entrepreneurship is a work option that is very familiar to them and they have a good ability in entrepreneurship as if it had been inherited. And there is a feeling of being proud of being a trader and not being an employee. This feeling arises because one of them is formed from the culture and traditions of their ancestors.

\section{References}

[1] F. Asmin, "Budaya dan Pembangunan Ekonomi: Sebuah Kajian terhadap Artikel Chavoshbashi dan Kawan-Kawan," J. Stud. Komun. (Indonesian J. Commun. Stud., vol. 2, no. 2, 2018.

[2] F.-J. Sun, "Analysis of the Relationship between Culture, Economy and Politics," in 3rd Annual International Conference on Social Science and Contemporary Humanity Development (SSCHD), 2017, vol. 90.

[3] K. Tsuyushi, Adat Minangkabau dan merantau dalam perspektif sejarah. Jakarta: Balai Pustaka, 2005.

[4] D. Indrayani, "Konstruksi sosial budaya minangkabau atas pasar," J. Antropol. Isu-Isu Sos. Budaya, vol. 18, no. 1, 2016.

[5] Y. Huda, Contesting sharia: state law, decentralization and Minangkabau custom. Leiden: Leiden University, 2013.

[6] P. C. Hastuti, A. Thoyib, E. A. Troena, and and M. Setiawan, "The Minang Entrepreneur Characteristic," in Procedia -Social and Behavioral Sciences, 2015, vol. 211, pp. 819-826. 